\title{
Financial Deepening and Capital Market Returns in Nigeria
}

\author{
Ogbonna Udochukwu Godfrey ${ }^{1}$, Ejem Chukwu $\operatorname{Agwu}^{2,}$, \\ ${ }^{1}$ Department of Management Science, Rhema University, Aba, Nigeria \\ ${ }^{2}$ Department of Banking and Finance, Abia State University, Uturu, Nigeria
}

Email address:

ecjah71@yahoo.com (E. C. Agwu)

${ }^{*}$ Corresponding author

\section{To cite this article:}

Ogbonna Udochukwu Godfrey, Ejem Chukwu Agwu. Financial Deepening and Capital Market Returns in Nigeria. Journal of Finance and Accounting. Vol. 8, No. 4, 2020, pp. 182-189. doi: 10.11648/j.jfa.20200804.13

Received: June 19, 2020; Accepted: July 1, 2020; Published: July 6, 2020

\begin{abstract}
This study applied the error correction model to examine the relationship between financial deepening and capital market returns in Nigeria. The study was conceived because of the importance of capital market as an engine and fulcrum that propel economic growth. As such, the degree of financial services it receives should be a matter of concern to finance and economic researchers. However, after empirical analysis of data obtained from the central bank of Nigeria and the National Bureau of Statistic, it was majorly found that the ratio of money supply to gross domestic product has a positive and significant impact on the returns of the capital market of Nigeria. It was also found that ratio of credit to private sector to gross domestic product has negative and significant influence on the return of the capital market in Nigeria. In the light of these findings, the researchers advise the central bank of Nigeria to always do proper evaluation and monitoring of the distribution of such financial services, aimed at ensuring it gets to the targeted individuals, thereby stimulating economic growth in Nigeria. In addition, supervisory authorities of the capital market in Nigeria should in her advisory role, organize technical sections for investors on the rechanneling of their returns in the exchange. This will go a long to increase the capitalization of the capital market.
\end{abstract}

Keywords: All Share Index, Financial Deepening, ECM, Nigeria

\section{Introduction}

One of the important roles of capital market, a component of financial system of any country is mobilization of financial resources as well as the allocation of the same to the asking units of the economy. The capital market prominence is as a result of the pooling of funds together from the lenders (saving-surplus units) to the borrowers (saving-deficit units). In fact, capital market, just like every other financial intermediary such as banks is a conduit pipe through which the savings of the public are first aggregated and thereafter disaggregated to the various economic units of the economy. This is one of the investments banking function of capital market as captured in financial intermediation. The capital market, in the process of fund mobilization will spur the growth and development of the economy in general and will enhance the liquidity of firms for investment. Hence, capital markets increase economic efficiency, investment and growth $[15,13,16,26,37]$.
Stock exchanges which are an important segment of the stock market are intricately interwoven in the fabric of a nation's economic life. Without a stock exchange, the saving of the community, the sinews of economic progress and productive efficiency would remain underutilized. The task of mobilization and allocation of savings could be attempted in the old days by a much less specialized institution than the stock exchange. But as business and industry expanded and the economy assumed more complex nature, the need for 'permanent finance' arose. Entrepreneurs needed money for long term whereas investors demanded liquidity; the facility to convert their investment into cash at any given time. The answer was a ready market for investments and this was how the stock market came into being [29, 18, 3, 4].

Financial deepening is seen by most finance and economic researchers as an increase in the stock of asset. It is a term used by economists to refer to increasing provision of financial services. It can also be seen as both a wider choice of services and better access for different socio-economic 
groups. Financial deepening can have an effect on both individuals' and societies' economic situations [35]. It is a process that particularly engages finance functions through organized domestic institution and financial markets. Financial deepening is also seen as a product of accepting appropriate real finance policy such as relating real rate of return to real stock of finance [34, 23, 27]. Financial deepening fundamentally engaged in the process of financial intermediation by channeling funds from the surplus units to deficit units. Financial deepening foresees the capacity of financial intermediaries to mop up savings for investment $[22,23]$. Financial deepening is a product of adoption of appropriate real finance policy and the broadening of the markets [34]. When a nation's financial market is efficient and effective, its intermediation process will result to welldeveloped and well-functioning financial sector with capacity to promote and support economic growth. Otherwise, financial shallowness retards economic development $[13,12$, 21].

In this case, the capital market is the engine that propels the economic growth. The doctrine of financial disequilibrium and intermediation imply the financial concepts of lending and borrowing. Finance tries to resolve the disequilibrium and ensure intermediation by bring the deficit units and the surplus units together within an institutional framework and market mechanism to consummate the needed financial transactions [10]. The interactions inherent in the capital market basically facilitate the exchange of funds between the surplus and deficit units of the economy. This process results to simultaneous creation of financial assets and financial liabilities. The resultant effect is consistent changes on claims and counter claims to financial assets, changes that represent financial flow or flow mechanism [24]. The important issue in the investment process is to achieving optimal financial flow, which greatly impact on the effectiveness of the facilities provided by the financial intermediaries. This of course is the core thrust of the study; financial deepening and capital market returns in Nigeria.

Meanwhile, the capital market as one of the financial intermediaries; an avenue for the interactions among the surplus and deficit economic units of any economy needs to be evaluated on the extent of financial services it receives and its spiral effect concerning the returns of the market. Again, finance and economic researchers have concentrated more work on financial deepening and economic growth, but needs to dwell more on the engine that propels the economic growth and development; the capital market. This concern incited the researchers work on this study, financial deepening and capital market returns relations in Nigeria. The subsequent sections are decomposed as follows; 2literature review, 3-Methodology, 4- Results and Interpretation and 5-Conclusion and Recommendations.

\section{Literature Review}

The financial system of any economy; developed, developing or underdeveloped consists of a whole range of financial intermediation, such as various types of banks (money market) and capital markets. Financial intermediaries provide asset holders with the assets which are more liquid than those issued by ultimate borrowers. The principle of financial intermediation is basic to them all. The financial intermediary borrows by issuing claims on it, known as secondary claims, which are more liquid than the assets the financial intermediary requires. As a result of financial intermediation, a whole stock of financial assets and liabilities is built up over time and offers lenders and borrowers a range of financial instruments which differ in marketability, risk and rate of return [19].

Absence of financial intermediations in any economy slows down the pace fund flows between economic agents. This is because; the moment money is lent to firms by buying its financial claims, investors need to monitor the actions of the firm. They must ensure that the firm's management neither absconds with nor wastes the funds on any investments with low or negative net present values. This kind of monitoring activity is extremely costly for investor since they require considerable time and expense to collect sufficiently high quality information relative to the size of average investor's investments. Consequently, any investor would prefer to leave the monitoring to another; in the end, little or no monitoring would be done. The outcome of lack of monitoring would definitely reduce the attractiveness and increase the risk of investing in corporate debt and equity. This situation is assumed to retard the returns of the capital market and negatively affect the economy.

More so, even if capital markets existed (without the financial intermediaries to man them) to provide liquidity services by allowing investors to trade corporate debt and equity securities among themselves, investors also face a price risk on sale of securities, and the capital market trading of securities involves various transaction costs. That is, the prices at which investors can sell securities on the secondary market (capital market) like the Nigeria Stock Exchange may well differ from the price they paid for the securities abnitio [32]. In words of Saunders and Cornett [32], due to monitoring costs, liquidity costs and price risk, the investor saver may view direct investment in corporate securities as an unattractive proposition and prefer either not to save or to save in the form of cash. However, the economy has developed an alternative and indirect way to channel economic agent's (investor) savings to the corporate sector. This is to channel savings through financial intermediaries. Again due to the already mentioned costs (monitoring costs, liquidity costs and price risk) as well as other pertinent reasons, savers most times prefer to hold the financial claims issued by financial intermediaries like the capital market rather than those issued by corporations.

\subsection{Theoretical Literature}

The Keynesian theory of financial deepening asserts that financial deepening occurs due to an expansion in 
government expenditure. In order to reach full employment, the government should inject money into the economy by increasing government expenditure. An increase in government expenditure increases aggregate demand and income, thereby raising demand for money [21].

Capital Asset Pricing Model (CAPM): For the purpose of pricing or determining the prices of individual securities in the capital market, CAPM was introduced. This model (CAPM) was developed by William F Sharpe and John Linter in 1963 and 1964 as testable model for determining the value of individual securities or portfolio. This model is a significant departure from the efficient market model, which focused attention on the risk - return features of portfolio $[33,20,11]$. The CAPM contends that the expected return on any asset is a linear function of its systematic risk. According to Cuthbertson and Nitzsche [7] it predicts that only the covariance of returns between asset- $i$ and the market portfolio influences the excess return on asset- $i$. In sum CAPM is a testable model for determining the prices of financial asset with a single factor, though with inherent limitation of CAPM; it is based on unrealistic assumptions, it is difficult to test the validity of CAPM, betas do not remain stable over time and CAPM is single factoral (has only one factor) $[17,4,5]$.

The Arbitrage Pricing Theory (APT): Because of the sighted limitations of the CAPM, the theory of Arbitrage Pricing was evolved by Stephen Ross in 1976. Stephen Ross argued clearly that in a situation where different portfolios with multiple factors (betas) exist, CAPM with one-factor model (one beta) may not be able to produce the desired results (actual returns) for efficient portfolio. APT allows the actual return to be influenced by a number of market wide variables or factors such as interest rate, the exchange rate, change in inflation, change in output etc. The sensitivity of the return on asset to each of these factors is known as the 'factor beta'. Economic variables have a systematic consequence on stock market returns because economic forces affect discount rates, the ability of the firm to generate cash and future dividend payments $[6,9]$. The APT is a multifactor model since unlike the CAPM allows a number of potential variables (factors) to influence the expected on asset- $i[7,17,4]$.

\subsection{Empirical Literature}

Many empirical literatures abound in Nigeria on the relationship between financial deepening and economic growth, but much have not been done on the financial deepening and capital market relations. The essence of this research is to unravel the impact of financial deepening on the capital market returns in Nigeria; which is the engine that propels growth and development. However, Omole [28] used econometric multiple regression analysis to examine the relationship between financial deepening and stock market, based on the Nigerian evidence from 1970 to 1994. It was found, despite the fact that financial deepening remains weak in Nigeria, given the magnitude of overall economic activities, it had the ability to stimulate the development of the stock market. This shows that the level of financial services will automatically enhance the performance of the capital market despite the level of services at a particular time.

Enisan and Olufisayo [8] employed autoregressive distributed lag (ARDL), to empirically investigate thelongrunrelationshipbetweenstockmarketdevelopmentandeconomi cgrowthinseven of the Sub-Saharan African countries (Nigeria, South Africa, Egypt, Cote D'Ivoire, Kenya, Morocco and Zimbabwe). The results found that stock market impact positively and significantly on growth in all the seven countries examined.

Applying GARCH $(1,1)$ model, Okoli [25] investigated the relationship between financial deepening and stock market returns and volatility in the Nigerian stock market. In the study, Financial deepening was proxied by two variables, the ratio of the value of stock traded to GDP (FD1t) and the ratio of market capitalization to GDP (FD2t). the results found that financial deepening (FD1t) measured as the ratio of value of stock traded to GDP do not affect the stock market and there is no news about volatility, whereas, financial deepening (FD2t) measured as the ratio of market capitalization to GDP affect the stock market.

Employing multiple regression technique and VECM, Alenoghena, Enakali-Osoba and Mesagan [2], studied the impact of financial deepening on the performance of the Nigerian capital market from 1981 to 2012. The result revealed that financial deepening variables have positive impact on the performance of the Nigerian stock market. The study further showed Narrow Money Diversification (NMD; involving size of commercial banks' demand deposit) and the growth of Savings (SAVR) has significant impact on the performance of the Nigerian stock market, whereas, Income (GDP) and Financial Development (FID; involving credit to private sector) is positive and insignificant on the performance of the capital market. In the same vein, Alenoghena [1] used the error correction mechanism model to examine the impact of capital market and financial deepening to economic growth in Nigeria from 1981 to 2012. The study revealed that Stock Market Capitalization (MCAP), Narrow Money Diversification (NMD; involving credit to private sector) and Interest Rate (INT) have significant impact on the economic growth, also liquidity represented by Financial Development (FID) and Monetization Ratio (MTR) insignificantly impact economic growth.

Rahman and Mustafa [31] engaged Pedroni's panel cointegration methodology and panel vector error-correction models to empirically test the effects of stockmarket turn over and liquidity, as measures of financial deepening, on stockmarket returns in selected 19 developed and 21 developing countries from 1988 to 2014. The results found that Stockmarket turn over impacts greater tostockmarketreturnsthanstockmarketliquidityinbothselectedd evelopedanddevelopingeconomies. This shows that the outputs are much weaker for developing countries than for developed countries. 


\section{Methodology}

\subsection{Variables and Sources of Data}

The dependent variable in this study is capital market returns proxied by All share Index (ASI) while, the independent variables are Ratio of Money Supply to Gross Domestic Product (MS/GDP) and Ratio of Credit to Private Sector to Gross Domestic Product (CPS/GDP). MS/GDP and CPS/GDP are among the measures of financial deepening $[12,27]$. These variables formed the data for the empirical investigation for this study, capital market and financial deepening relations obtained from Central Bank of Nigeria (CBN) Statistical Bulletin and National Bureau of Statistics from 1985 to 2018.

\subsection{Techniques}

Here, Correlation Matrix is used to check multicolinearity of the variables. In testing the stationarity of the variables, the Augmented Dickey Fuller (ADF) unit root test is engaged; also to examine if long run relationship exists between the dependent and independent variables in this paper, Johansen Cointegration is used. Error Correction Model (ECM) is employed to testing the models

\subsection{Model Specification}

The functional form;

Capital Market Returns $=\mathrm{f}($ Financial deepening Variables $)(1)$
All share Index $=\mathrm{f}$ (Ratio of Money Supply to Gross Domestic Product, Ratioof Credit to Private Sector to Gross Domestic Product)

$$
\mathrm{ASI}=\mathrm{f}(\mathrm{MS} / \mathrm{GDP}, \mathrm{CPS} / \mathrm{GDP})
$$

Then, the explicit form;

$$
\mathrm{ASI}_{\mathrm{t}}=\alpha_{01}+\alpha_{1} \mathrm{MS} \mathrm{GDP}_{\mathrm{t}-1}+\alpha_{2} \mathrm{CPS} / \mathrm{GDP}_{\mathrm{t}-1}+\mathrm{U}_{\mathrm{t} 1}
$$

The Operational form (Apriori Expectation);

$\alpha_{1}$ and $\alpha_{2}>0<0$, are coefficient of MS/GDP and CPS/GDP. It is expected that financial deepening variables either positively or negatively relate with capital market returns in Nigeria.

Where,

MS/GDP = Ratio of Money Supply to Gross Domestic Product

CPS/GDP $=$ Ratio of Credit to Private Sector to Gross Domestic Product, $\mathrm{U}_{\mathrm{t} 1}=$ Error term

\section{Results and Interpretation}

\subsection{Trend Analysis}

Let's examine the data features of sources for the analysis. Figure 1 below shows upward movement with periods with peaks and troughs suggesting mild fluctuations in the distribution and non-stationarity of the variables as expected.

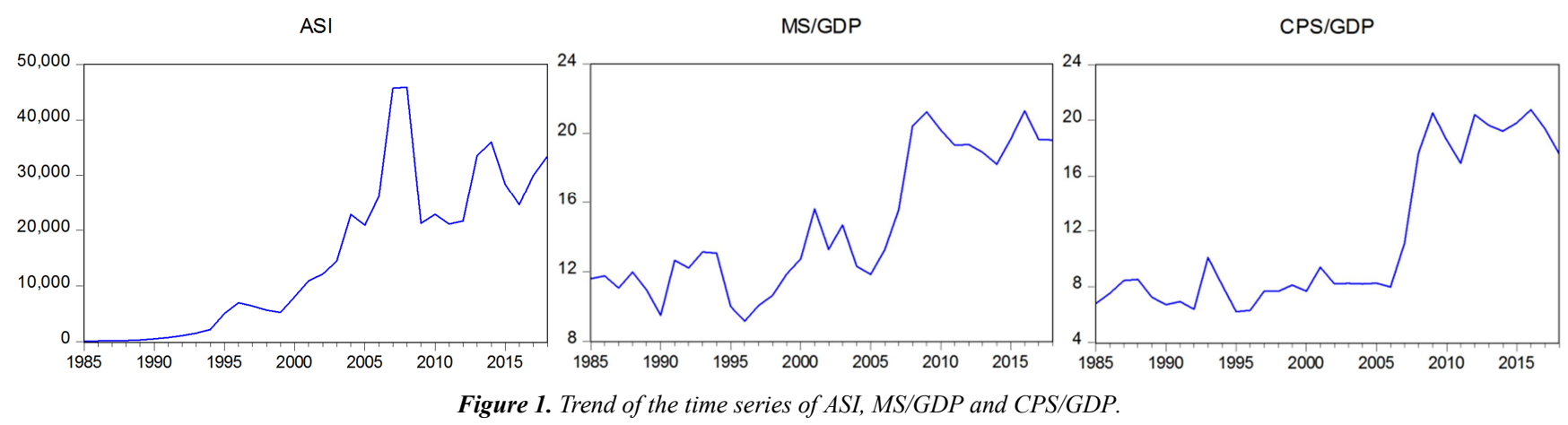

\subsection{Descriptive Statistics}

Table 1 below shows the summary of statistics that describe the distributional features of all the data. The variables recorded mean of $15205.34,14.61$ and 11.55 for ASI, MS/GDP and CPS/GDP respectively, while the respective standard deviations are 13992.32, 3.95 and 5.47 reflecting high level of dispersion from the mean. ASI, MS/GDP and CPS/GDP revealed kurtosis lower than 3 showing platykurtic distributions. All the variables recorded positive stewed distribution. That means the distributions have long right tail. Jarque-Bera normality distribution test statistic recorded probability values of $0.247707,0.165159$ and 0.070191 for ASI, MS/GDP and CPS/GDP respectively, indicatingabnormal distributions at 5\% significance level.
Table 1. Descriptive Statistics ASI, MS/GDP and CPS/GDP.

\begin{tabular}{llll}
\hline & ASI & MS_GDP & CPS_GDP \\
\hline Mean & 15205.34 & 14.61367 & 11.55074 \\
Median & 11550.40 & 13.09787 & 8.249338 \\
Maximum & 45908.88 & 21.30726 & 20.77330 \\
Minimum & 127.3000 & 9.151674 & 6.217349 \\
Std. Dev. & 13992.32 & 3.951751 & 5.473608 \\
Skewness & 0.594577 & 0.439041 & 0.714269 \\
Kurtosis & 2.254319 & 1.669083 & 1.692454 \\
Jarque-Bera & 2.791014 & 3.601687 & 5.313064 \\
Probability & 0.247707 & 0.165159 & 0.070191 \\
Sum & 516981.6 & 496.8647 & 392.7252 \\
Sum Sq. Dev. & $6.46 \mathrm{E}+09$ & 515.3391 & 988.6926 \\
Observations & 34 & 34 & 34 \\
\hline
\end{tabular}

\subsection{Multicollinearity Test}

Table 2 below reveals the correlation matrix of the 
variables. The correlation between ASI, MS/GDP and CPS/GDP ranges from 0.726535 to 0.952541 , suggesting that in the variables noperfectlinear correlation. Therefore, the researchers have enough evidence to declare no presence of multicollinearity in the model.

Table 2. Correlation Matrix of ASI, MS/GDP and CPS/GDP.

\begin{tabular}{llll}
\hline Variables & ASI & MS_GDP & CPS_GDP \\
\hline ASI & 1.000000 & 0.754060 & 0.726535 \\
MS_GDP & 0.754060 & 1.000000 & 0.952541 \\
CPS_GDP & 0.726535 & 0.952541 & 1.000000 \\
\hline
\end{tabular}

Table 3. Regression Test for ASI, MS/GDP and CPS/GDP.

\section{Dependent Variable: LogASI \\ Method: Least Squares}

\begin{tabular}{lllll} 
Variable & Coefficient & Std. Error & t-Statistic & Prob. \\
\hline LogMS_GDP & 3.289778 & 2.845780 & 1.156020 & 0.2565 \\
LogCPS_GDP & 0.802537 & 1.713228 & 0.468436 & 0.6428 \\
C & -0.824191 & 1.727879 & -0.476996 & 0.6367 \\
R-squared & 0.430514 & F-statistic & & 11.71751 \\
Adjusted R-squared & 0.393773 & Prob (F-statistic) & & 0.000162 \\
Durbin-Watson stat & 0.206334 & & & \\
\hline
\end{tabular}

\subsection{Stationarity/Unit Root Test}

This is statistical valid procedure for macroeconomics time series analysis that helps to determining the best estimation method for a model. This is because of the peculiarities of time series data. To do this the popular Augmented Dickey

\subsection{Regression Test}

The researchers decided to engage regression technique to examine the relationship between financial deepening and capital market returns as shown below;

Table 3 shows Regression estimated model for the relationship between financial deepening and capital market returns. From the table Durbin-Watson statistics is 0.206334, indicating presence of autocorrelation. This is unreliable and calls for further examination.
Fuller (ADF) unit root/stationary test is engaged as shown below.

Table 4 shows the summary of stationary test. The results revealed that all the variables; ASI, MS/GDP and CPS/GDP are difference once to be stationary, hence good for ECM estimations

Table 4. Augmented Dickey Fuller Unit Root Test.

\begin{tabular}{|c|c|c|c|c|c|c|c|c|}
\hline \multirow{3}{*}{ Variables } & \multirow{3}{*}{ Maxlag } & \multicolumn{3}{|l|}{ LEVEL } & \multicolumn{3}{|l|}{$1^{\text {st }}$ DIFFERENCE } & \multirow{3}{*}{ Rmk } \\
\hline & & \multirow{2}{*}{ ADF Stat/P-value } & \multicolumn{2}{|c|}{ Critical Values } & \multirow{2}{*}{ ADF Stat/P-value } & \multicolumn{2}{|c|}{ Critical Values } & \\
\hline & & & $5 \%$ & $10 \%$ & & $5 \%$ & $10 \%$ & \\
\hline ASI & 8 & $-2.672055(0.0896)$ & -2.954021 & -2.615817 & $-4.053555(0.0037)$ & -2.957110 & -2.617434 & (a) 1(1) \\
\hline MS/GDP & 8 & $-1.118531(0.6966)$ & -2.954021 & -2.615817 & $-5.542586(0.0001)$ & -2.957110 & -2.617434 & (a)1(1) \\
\hline CPS/GDP & 8 & $-0.966041(0.7536)$ & -2.954021 & -2.615817 & $-4.639565(0.0008)$ & -2.960411 & -2.619160 & @ 1(1) \\
\hline
\end{tabular}

\subsection{Cointegration and Long Run Relationship Test}

Here the researchers proceeded to examine if there exist equilibrium relationships between the variables; capital market returns indicator (ASI) and financial deepening variables (MS/GDP and CPS/GDP) as shown below;

Table 5. Johansen Cointegration Test.

\begin{tabular}{|c|c|c|c|c|}
\hline \multicolumn{5}{|c|}{ Unrestricted Cointegration Rank Test (Trace) } \\
\hline Hypothesized & & Trace & 0.05 & \\
\hline No. of CE(s) & Eigenvalue & Statistic & Critical Value & Prob.** \\
\hline None * & 0.495300 & 35.69283 & 29.79707 & 0.0093 \\
\hline At most 1 & 0.306561 & 15.17912 & 15.49471 & 0.0557 \\
\hline At most $2 *$ & 0.130537 & 4.196375 & 3.841466 & 0.0405 \\
\hline
\end{tabular}

Trace test indicates 1 cointegrating eqn(s) at the 0.05 level

\subsection{Contemporaneous Relationship Between ASI, MS/GDP and $C P S / G D P$}

This is necessary to determine the relationship between
Table 5 below shows that unrestricted rank tests (Trace) revealed two cointegration equations at $5 \%$ level of significant (noneand at most 2). This is a good evidence to show that long run relationship exists between the dependent variable capital market returns (ASI) and independent variables; financial deepening (MS/GDP and CPS/GDP). capital market returns and financial deepening. Remember that the Regression analysis shows unsatisfactory result, and was therefore abandoned. Therefore, the researchers therefore adopt Error Correction Model (ECM) to further examine the long run relationship between returns of capital 
market and financial deepening variables, and also capture the short run deviations of the parameters from the long run equilibrium by incorporating lagged residuals.

Table 6 below shows the result of the ECM. ASI at lag 1 has coefficient of 0.052183 and p-value of 0.5353 , which is insignificant at 5\% level, showing ASI is not autoregressive. MS/GDP at lag 2 has coefficient of 0.733127 with p-value of 0.0175 at $5 \%$ significant level. This shows that MS/GDP has positive and significant relationship with ASI, while CPS/GDP at lags 2 as well has coefficient of -0.493953 with p-value of $0.0343,5 \%$ significant level, indicating that CPS/GDP has negative and significant relationship with ASI. The Durbin-Watson statistics is 1.913497 showing no presence of autocorrelation in the model estimated, showing the model is suitable to adduce the Contemporaneous Relationship between capital market returns (ASI) and financial deepening (MS/GDP and CPS/GDP). The ECM has coefficient of 0.051877 and p-value of 0.0250 which is statistically significant, the model is correctly signed.

Table 6. Error Correction Model (ECM).

\begin{tabular}{llll}
\hline Dependent Variable: D(LOGCPS_GDP) & & \\
\hline Variable & Coefficient & Std. Error & t-Statistic \\
\hline D(LOGASI(-1)) & 0.052183 & 0.083016 & 0.628589 \\
D(LOGMS_GDP(-1)) & 0.334518 & 0.290534 & 1.151389 \\
D(LOGMS_GDP(-2)) & 0.733127 & 0.288082 & 2.544859 \\
D(LOGCPS_GDP(-1)) & -0.062329 & 0.208204 & -0.299363 \\
D(LOGCPS_GDP(-2)) & -0.493953 & 0.220589 & -2.239244 \\
ECM(-1) & 0.051877 & 0.021758 & 2.384280 \\
R-squared & 0.372834 & Durbin-Watson stat & 0.2605 \\
Adjusted R-squared & 0.247401 & S. D. dependent var & 0.7671 \\
\hline
\end{tabular}

\subsection{Causal Relationship Between ASI, MS/GDP and CPS/GDP}

In macroeconomic analysis, causality test is common tool used to check if causality exists or otherwise, between any two variables.
Table 7 below shows that ASI granger causes MS/GDP (Fstat $_{\mathrm{ASI}}=7.87660 ; \operatorname{Prob}_{\mathrm{ASI}}=0.0020$, significant at $5 \%$ ). In the same way, ASI granger causes CPS/GDP $\left(\mathrm{F}_{-}\right.$stat $_{\mathrm{ASI}}=$ 9.00815; $\operatorname{Prob}_{\mathrm{ASI}}=0.0010$, significant at 5\%). That shows unidirectional causality between ASI and MS/GDP, CPS/GDP

Table 7. Pairwise Granger Causality Test Results.

\begin{tabular}{|c|c|c|c|}
\hline Null Hypothesis: & Obs & F-Statistic & Prob. \\
\hline MS_GDP does not Granger Cause ASI & 32 & 0.67949 & 0.5153 \\
\hline ASI does not Granger Cause MS_GDP & & 7.87660 & 0.0020 \\
\hline CPS_GDP does not Granger Cause ASI & 32 & 1.27510 & 0.2957 \\
\hline ASI does not Granger Cause CPS_GDP & & 9.00815 & 0.0010 \\
\hline
\end{tabular}

\subsection{Residual/Diagnostic Check}

The table 8 below shows that Heteroscedasticity Test: ARCH F-Statistic has P-value of 0.7802, suggesting no presence heteroscedasticity in the model. Also, table 9 shows that Breusch-Godfrey Serial Correlation LM Tests has FStatistic with P-value of 0.4143 , which shows of non rejection of the null hypothesis, an indication of absence of serial correlation.

Table 8. Heteroscedasticity Test: $A R C H$.

\begin{tabular}{llll}
\hline Heteroskedasticity Test: ARCH & & \\
\hline F-statistic & 0.079377 & Prob. F(1,28) & 0.7802 \\
Obs*R-squared & 0.084807 & Prob. Chi-Square (1) \\
\hline
\end{tabular}

Table 9. Breusch-Godfrey Serial Correlation LM Tests.

\begin{tabular}{llll}
\hline \multicolumn{3}{l}{ Breusch-Godfrey Serial Correlation LM Test: } & \\
\hline F-statistic & 0.915813 & Prob. F(2,23) & 0.4143 \\
Obs*R-squared & 2.286617 & Prob. Chi-Square (2) & 0.3188 \\
\hline
\end{tabular}

\subsection{Normal Distribution Check}

Figure 2 below revealed that Jarque-Bera Statistic coefficient is 0.154992 with P- value of 0.925431 , a clear evidence of normal distribution. 


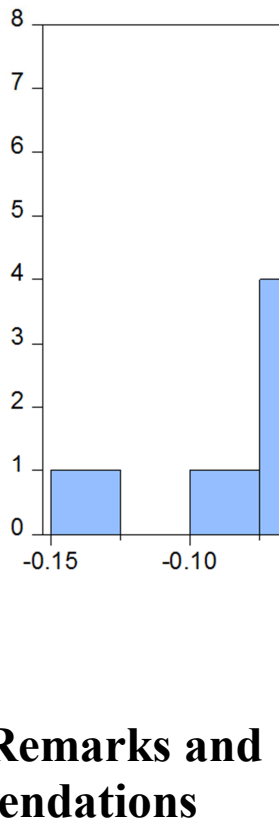

The models specified and established in this study, impact of financial deepening on the capital market returns in Nigeria proved very useful judging from the global utility outcomes of multicollinearity, the diagnostic tests of heteroscedasticity and serial correlation as well the result of normality distribution test. It also agrees with the apriori expectation of the study. Having satisfied with the aforementioned, it was mainly found that the ratio of money supply to gross domestic product has a positive and significant impact on the returns of the capital market of Nigeria. The veracity is not in doubt as the monetary policy transmission instruments of the central bank of Nigeria have in several occasions found to be very effective in financial intermediation in Nigeria. This is in agreement with the Keynesian theory of financial deepening, that financial deepening occurs due to an expansion in government expenditure. In order to reach full employment, the government should inject money into the economy by increasing government expenditure. An increase in government expenditure increases aggregate demand and income, thereby raising demand for money [21]. It was also found that ratio of credit to private sector to gross domestic product has negative and significant influence on the return of the capital market in Nigeria. This result is a confirmation of suspected misplacement of priority in the extension of financial services in Nigeria. The central bank of Nigeria in her various anchor programmes through the various state governors have not succeeded in stimulating economic growth. This is because such financial assistances are not always properly utilized or are diverted for non productive purposes aided by elected and non elected public office holders. In the light of these findings, the researchers advise the central bank of Nigeria to always do proper evaluation and monitoring of the distribution of such financial services, aimed at ensuring it gets to the targeted individuals/organizations, thereby stimulating economic growth in Nigeria. In addition, supervisory authorities of the

\begin{tabular}{|lr|}
\hline \multicolumn{2}{|l|}{ Series: Residuals } \\
Sample 1988 2018 \\
Observations 31 \\
Mean & 0.002488 \\
Median & -0.001560 \\
Maximum & 0.127644 \\
Minimum & -0.132726 \\
Std. Dev. & 0.058735 \\
Skewness & 0.138854 \\
Kurtosis & 2.792945 \\
& \\
Jarque-Bera & 0.154992 \\
Probability & 0.925431 \\
\hline
\end{tabular}

$0.10 \quad 0.15$

capital market in Nigeria should in her advisory role, organize technical sections for investors on the rechanneling of their returns in the Nigerian Stock Exchange. This will go a long to increase the capitalization of the capital market.

\section{References}

[1] Alenoghena, R. O. (2014). Capital market, financial deepening and Nigerian economic growth: Cointegration and error correction model approach. Global Journal of Commerce and Management Perspective, 3 (3), 18-26.

[2] Alenoghena, R. O., Enakalii-Osoba, C. \& Mesagan, P. E. (2014). Financial deepening and performance of the Nigeria capital market: Empirical evidence. Global Journal of Commerce and Management Perspective, 3 (4), 142-151.

[3] Ang, J. B., (2007). Financial deepening and economic development in Malaysia. Asian BusinessAnd Economics Research Unit, Discussion Paper 42.

[4] Bhalla, V. K. (2011). Investment management: Security analysis and portfolio management. NewDelhi: S. Chadand Company Ltd.

[5] Bodie, Z., Kane, A., Marcus, A. J. \& Mohanty, P. (2013). Investment ( $8^{\text {th }}$ editon). New Delhi: Mc Graw Hill Education.

[6] Chen, N. F., Roll, R. \& Ross, A. S. (1986). Economic force and the stock market. Journal of Business, 59 (4), 383-403.

[7] Cuthbertson, K. \& Nitzsche, K. (2005). Investments: Spot and derivatives market. New York: John Willey and Sons Ltd.

[8] Enisan, A. A. \& Olufisayo, A. O. (2009) Stockmarket development and economic growth: Evidence from seven subSahara African countries. Journal of Economics and Business, $61,162-171$.

[9] Essays, UK. (November 2018). Macroeconomic Variables and Nigerian Stock Market. Retrieved from https://ukdiss.com/litreview/macro-economic-variables-andnigerian-stock-market.php? vref $=1$

[10] Ezirim, C. B. (2005). Finance Dynamics: Principles, techniques and applications $\left(3^{\text {rd }} e d\right)$. Portharcourt: Markowitz Centre for Research and Development. 
[11] Fama, E. F. \& French, K. R. (2004). The capital asset pricing model: Theory and evidence. Journal of Economic Perspective, 8 (3), 25-46.

[12] Ghani, E. (1992.). How financial markets affect long run growth: A cross country study. Policy Research Working Paper Series 843, the World Bank.

[13] Goldsmith, R. W. (1969). Financial structure and development. Yale: University Press, New Haven.

[14] Greenwood, J. \& Jovanoic, B. (1990). Financial development, growth, and the distribution of income. Journal of Political Economy, 98, (5), 1076-1107.

[15] Gurley, J. G. \& Shaw, E. S. (1955). Financial aspects of economic development. American Economic Review, 45, 515538 .

[16] Hicks, J. R. (1969). A theory of economic history. Oxford: Oxford University Press.

[17] Ibenta, S. N. (2005). Investment analysis and financial management strategy. Enugu: Institute of Development Studies.

[18] Ilaboya, O. J. \& Ibrahim, S (2004). Impact of stock market performance on the level of economic activities: Evidence from Nigerian stock market. Nigerian Journal of Business Administration, 6 (1).

[19] Levacic, R. \& Rebmann, A. (1982). Macroeconomics: An introduction to Keynesian-Neoclassical controversies. New York: Macmillian.

[20] Lintner, J. (1965). The valuation of risk assets and the selection of risky investments in stockportfolios and capitalbudgets. Review of Economics and Statistics, 4 (1), 1337.

[21] McKinnon, R. I. (1973). Money and capital in economic development. Washington DC: Brookings Institution.

[22] Ndekwa (1998). Financial intermediation and economic growth in developing growth. Journal of Economic Studies, 2 , 203-234.

[23] Nnanna, O. J. \& Dogo, M. (1998). Structural reform, monetary policy and financial deepening: the Nigerian experience. Economic and Financial Review, 36, 1-29.
[24] Okafor, F. O. (1983). Investment decisions: Evaluation of projects and securities. London: Cassell.

[25] Okoli, M. N. (2012). Evaluating the nexus between financial deepening and stockmarket in Nigeria. European Scientific Journal, 8 (15), 18-29.

[26] Olashore, O. (1985). Bank management in Nigeria. Lagos: IBWA-Afribank.

[27] Oloyede, A. (1998). The financial system's role in resource mobilization and investment: Ananalysis of financial deepening in Nigeria's financial sector. In the dynamics of managing the Nigerian financial system in the 21 st century. $A$ Publication of the Central Bank of Nigeria.

[28] Omole, D. A. (1999). Financial deepening and stockmarket development in Nigeria. NISERMonograph Series, No. 15.

[29] Osaze, B. E. \& Anao, A. R. (1999). Managerial finance. Benin City: UNIBEN Press.

[30] Popiel, P. A. (1990). Developing financial markets, international finance corporation, Washington: Brookings Institution.

[31] Rahman, M \& Mustafa, M. (2017). Financial deepening and stock market returns: Panel data analyses for selected developed and developing economies. International Journal of Monetary Economics and Finance, 10 (1) 96-109.

[32] Saunders, A. \& Cornett, M. (2006). Financial institutions management: A risk management approach. New York: McGraw-Hill.

[33] Sharpe, W. F. (1964). Capital asset price: A theory of market equilibrium under conditions of risk. Journal of Finance, 19 (3), 425-442.

[34] Shaw, E. S. (1973). Financial deepening in economic development. New York: Oxford University Press.

[35] Wikipedia https://en.wikipedia.org/wiki/Financial_deepening.

[36] World Bank (1989). World Development Report.

[37] Yartey C. O. \& Adjasi C. K. (2007). Stock market development in Sub Saharan Africa: Critical issues and challenges. International Monetary Fund working paper No. wp/07/209. 